\title{
The putative androgen receptor-A form results from in vitro proteolysis
}

\section{W Gregory ${ }^{1,2}, \mathrm{~B} \mathrm{He}^{1,3}$ and E M Wilson ${ }^{1,3}$}

${ }^{1}$ Laboratories for Reproductive Biology, Department of Pediatrics, Lineberger Comprehensive Cancer Center, University of North Carolina, Chapel Hill, North Carolina 27599, USA

${ }^{2}$ Department of Surgery, Division of Urology, University of North Carolina, Chapel Hill, North Carolina 27599, USA

${ }^{3}$ Department of Biochemistry and Biophysics, University of North Carolina, Chapel Hill, North Carolina 27599, USA

(Requests for offprints should be addressed to E M Wilson, Laboratories for Reproductive Biology, CB\#7500, Room 374, Medical Sciences Research Building, University of North Carolina, Chapel Hill, North Carolina 27599, USA; Email: emw@med.unc.edu)

\begin{abstract}
Activation domains in the $114 \mathrm{kDa}$ androgen receptor (AR) $\mathrm{NH}_{2}$ - and carboxyl-terminal regions are thought to contribute to different extents to AR-mediated transactivation. We investigated using anti-peptide antibodies whether smaller AR forms that migrate like the previously described $87 \mathrm{kDa}$ AR-A occur in vivo resulting in constitutive or increased gene activation. Immunoblots of prostate cancer and fibroblast cell culture extracts revealed 114 and $84 \mathrm{kDa}$ AR forms. Antibody mapping indicated the $84 \mathrm{kDa} \mathrm{AR}$ lacked the ligand-binding domain and comigrated with the constitutively active AR fragment AR1-660. AR expressed in COS cells was 114 and $92 \mathrm{kDa}$. Migration of the $92 \mathrm{kDa}$ AR was slightly slower than that of a $90 \mathrm{kDa}$ expressed fragment that was designed to initiate at
\end{abstract}

the second methionine (residue 189) and lacked the $\mathrm{NH}_{2}$-terminal FxxLF interaction sequence. The $92 \mathrm{kDa}$ AR did not result from alternative initiation since it was observed when the second methionine was changed to alanine. Optimization of extraction conditions indicated that both 84 and $92 \mathrm{kDa}$ forms resulted from in vitro proteolytic cleavage and that cleavage by caspase- 3 could account for the $92 \mathrm{kDa}$ form. The results suggest that AR forms with gel mobility similar to that of the previously described $87 \mathrm{kDa}$ AR-A result from in vitro proteolytic cleavage of $\mathrm{NH}_{2}-$ or carboxyl-terminal regions during cell extraction and storage and that smaller forms with increased transcriptional activity do not occur in vivo.

Fournal of Molecular Endocrinology (2001) 27, 309-319

\section{INTRODUCTION}

Steroid hormone receptors occur naturally in multiple forms. These include A and B forms of the progesterone receptor (PR) (Horwitz \& Alexander 1983, Krett et al. 1988, Kastner et al. 1990b), estrogen receptor $\alpha$ and $\beta$ (Kuiper et al. 1996, Mosselman et al. 1996), glucocorticoid receptor (GR) $\alpha$ and $\beta$ (Hollenberg et al. 1985, Oakley et al. 1996), and most recently, GR-A and -B (Yudt \& Cidlowski 2001). Estrogen receptor and GR $\alpha$ and $\beta$ are products of separate genes (Kuiper et al. 1996, Oakley et al. 1996) whereas PR-A and -B result from alternative promoter usage of the same gene (Kastner et al. 1990b) and GR-A and -B derive from alternative initiation at the first and second methionines (Yudt \& Cidlowski 2001). The shorter 769 amino acid PR-A lacks $164 \mathrm{NH}_{2}$-terminal amino acid residues whereas full-length PR-B is 933 amino acid residues in length (Horwitz \& Alexander 1983, Krett et al. 1988, Kastner et al. 1990b). The two PR forms can be present at nearly equimolar amounts (Horwitz \& Alexander 1983, Feil et al. 1988) and are hormonally and developmentally regulated (Spelsberg \& Halberg 1980, Kato et al. 1993, Mangal et al. 1997). Differences occur in their subcellular localization (Lim et al. 1999), activation by cAMP (Sartorius et al. 1994) and extent of phosphorylation (Clemm et al. 2000).

$\mathrm{A}$ and $\mathrm{B}$ forms were also reported for the androgen receptor (AR). An $87 \mathrm{kDa}$ AR-A lacked part of the $\mathrm{NH}_{2}$-terminal region analogous to PR-A 
and comigrated with an expressed fragment that initiated at the second methionine at residue 189 (Wilson \& McPhaul 1994). A survey of tissues indicated different ratios of the two AR forms, but in contrast to PR, the amounts of AR-A were only $\sim 10 \%$ of the amount of intact AR (Wilson \& McPhaul 1996, Gao \& McPhaul 1998). It was postulated that, like PR, AR-A occurs in vivo and has functional properties distinct from full-length AR (Wilson \& McPhaul 1994, Gao \& McPhaul 1998). Previous studies relied in part on AR expression where the sequence flanking the second methionine was altered to increase initiation at this position (Gao \& McPhaul 1998). Multiple forms of the AR were also reported in several fish species including rainbow trout (Takeo \& Yamashita 1999) and the Japanese eel (Ikeuchi et al. 1999). AR $\beta$ in rainbow trout fails to bind androgen whereas eel AR $\beta$ is functionally active. The lack of an additional AR sequence forthcoming from the human genome database combined with the phenotype of the syndrome of androgen insensitivity (Quigley et al. 1995) strongly supports the presence of only one active AR gene in humans.

Whether alternative forms of AR are expressed that lack either the $\mathrm{NH}_{2}-$ or carboxyl-terminal region is critical to understanding AR activity in vivo. For example, deletion of the carboxylterminal domain could result in a constitutively active receptor that increases androgen-regulated gene activation independently of ligand. Similarly, partial deletion of the $\mathrm{NH}_{2}$-terminal region as suggested for the previously reported AR-A would delete the ${ }^{23} \mathrm{FQNLF}^{27}$ sequence, which upon AR binding of high-affinity androgens, interacts with activation function 2 (AF2) in the ligand-binding domain (He et al. 1999). Interaction of ${ }^{23} \mathrm{FQNLF}^{27}$ with $\mathrm{AF} 2$ in the $\mathrm{NH}_{2}$ - and carboxyl-terminal interaction may limit AR activation by p160 coactivators (He et al. 2000, 2001). Loss of this $\mathrm{NH}_{2}$-terminal region in AR-A could potentially expose AF2 to enhanced activation and increased AR-mediated gene activation.

Our earlier investigations into multiple forms of $\mathrm{AR}$ indicated that they result from proteolytic degradation during isolation (Wilson \& French 1979). However, these studies were performed prior to the cloning of AR complementary DNA (Chang et al. 1988, Lubahn et al. 1988) and before the availability of anti-peptide antibodies directed against specific sequences in the AR (Tan et al. 1988, Quarmby et al. 1990, Prins et al. 1991, Zegers et al. 1991). We therefore reevaluated the origin of the $87 \mathrm{kDa} \mathrm{AR}-\mathrm{A}$ reported in various tissues and cell lines to determine whether these forms occur in vivo or are a result of proteolytic degradation.
In agreement with previous reports (Wilson \& McPhaul 1994, 1996, Gao \& McPhaul 1998), AR forms that migrate like AR-A were detected in cell and tissue extracts, particularly in frozen extracts prepared in the absence of dihydrotestosterone (DHT). By the analysis of several AR mutants and the use of anti-peptide antibodies specific to different regions of the $\mathrm{AR}$ and extraction conditions that minimize proteolysis, the data indicate that the previously described $87 \mathrm{kDa} \mathrm{AR}-\mathrm{A}$ and forms with similar migration by SDS gel electrophoresis result from in vitro proteolysis of the $\mathrm{NH}_{2}-$ or carboxyl-terminal region. The results further indicate that the presence of AR-A could be accounted for by in vitro cleavage at a predicted caspase- 3 cleavage site in the $\mathrm{NH}_{2}$-terminal domain.

\section{MATERIALS AND METHODS}

\section{Materials}

LNCaP, PC3 and COS-1 cell lines were purchased from the American Type Culture Collection (Rockville, MD, USA) and LNCaP-C4-2 cells from UroCor, Inc. (Oklahoma City, OK, USA). Control human foreskin fibroblast cultures (HFF-1) were previously described (Van Wyk et al. 1985, De Bellis et al. 1994). Fetal bovine serum was purchased from Hyclone Laboratories, Inc. (Logan, UT, USA), and DHT, antibiotics and cell culture media reagents were from Sigma Corp. (St Louis, MO, USA) or Gibco-BRL (Life Technologies, Grand Island, NY, USA).

\section{Tumor transplantation}

Male athymic nude mice 4-5 weeks of age were obtained from Harlan Sprague Dawley, Inc. (Indianapolis, IN, USA). CWR22 tumors were transplanted s.c. as dissociated cells in Matrigel (Wainstein et al. 1994, Nagabhushan et al. 1996) into mice containing testosterone pellets s.c. $(12.5 \mathrm{mg}$ for sustained release of $\sim 10 \mu \mathrm{g}$ testosterone/day; Innovative Research of America, Sarasota, FL, USA) to normalize mice to serum testosterone levels at $4 \mathrm{ng} / \mathrm{ml}$. Intact mice bearing androgen-stimulated tumors and recurrent CWR22 tumors resected 150 days after castration were exposed to methoxyflurane and killed by cervical dislocation. Tumors were removed immediately and frozen in liquid nitrogen. Animal procedures were approved by the Institutional Animal Care and Use Committee of the University of North Carolina at Chapel Hill. 


\section{Cell culture, plasmids and transfections}

LNCaP cells were maintained in RPMI medium containing $10 \%$ fetal bovine serum (Pietrzkowski et al. 1993). The LNCaP-C4-2 cell line derived from $\mathrm{LNCaP}$ cells after prolonged culture in the absence of androgen (Horoszewicz et al. 1983, Thalmann et al. 1994, Wu et al. 1994) was grown in $\mathrm{T}$ medium (DMEM/F12 with 5\% fetal bovine serum, $5 \mu \mathrm{g} / \mathrm{ml}$ insulin, $13.65 \mathrm{pg} / \mathrm{ml}$ triiodothyronine, $5 \mu \mathrm{g} / \mathrm{ml}$ apotransferrin, $0 \cdot 244 \mu \mathrm{g} / \mathrm{ml}$ d-biotin, and $25 \mu \mathrm{g} / \mathrm{ml}$ adenine). The CWR-R1 cell line developed from a recurrent CWR22 human prostate cancer xenograft (Gregory et al. 2001b) was maintained in prostate growth medium (Presnell et al. 1998) comprised of Richter's Improved MEM (Irvine Scientific, Santa Ana, CA, USA) supplemented with $10 \mathrm{mM}$ nicotinamide, $20 \mathrm{ng} / \mathrm{ml}$ epidermal growth factor, $5 \mu \mathrm{g} / \mathrm{ml}$ transferrin, $5 \mu \mathrm{g} / \mathrm{ml}$ insulin, $5 \mathrm{ng} / \mathrm{ml}$ selenium, 100 units $/ \mathrm{ml}$ penicillin, $100 \mu \mathrm{g} / \mathrm{ml}$ streptomycin, $0 \cdot 25 \mu \mathrm{g} / \mathrm{ml}$ fungizone and $2 \%$ fetal bovine serum. Monkey kidney COS-1 cells were maintained in DMEM with high glucose and $10 \%$ bovine calf serum, $20 \mathrm{mM}$ Hepes, $\mathrm{pH} 7 \cdot 2$, L-glutamine and antibiotics. COS cells $\left(1 \cdot 2 \times 10^{6}\right.$ cells $/ 10 \mathrm{~cm}$ dish) were transfected with wild-type and mutant pCMVhAR expression vector DNA $(10 \mu \mathrm{g})$ using DEAE dextran (Yarbrough et al. 1990). Human prostate cancer PC3 cells were maintained in DMEM/F-12 containing 10\% fetal

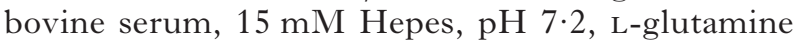
and antibiotics. PC3 cells were transfected with pCMVhAR $(0 \cdot 25 \mu \mathrm{g})$ using Effectine Transfection Reagent (Qiagen, Valencia, CA, USA) according to manufacturer's instructions. HFF-1 human foreskin fibroblasts were maintained in DMEM with high glucose containing $10 \%$ fetal bovine serum, L-glutamine, non-essential amino acids and antibiotics. HFF-1 cells derived from a primary culture of normal human foreskin were passed at least 14 times. Cell lines were passed every 4 days using trypsin/EDTA (Gibco-BRL).

Human AR expression vector $\mathrm{pCMVhAR}$ was modified to delete the first 188 residues. AR189919a deletion mutant was prepared by digesting pCMVhAR with BglII and AflI, followed by blunt ending and ligation. This construct deletes the first methionine and leaves the endogenous sequence that flanks the second methionine at residue 189 for initiation. A second mutant AR189-919b was created by inserting $5^{\prime}$ flanking sequence of the first methionine prior to the second methionine. This was done using an oligonucleotide primer similar to that previously described (Gao \& McPhaul 1998) that contains a $5^{\prime}$ BglII site followed by 28 base pairs of $5^{\prime}$ flanking non-coding sequence, ATG codon 189 and subsequent human AR sequence. pCMVhAR was digested with BglII and BstEII and ligated with the BglII/BstEII PCR amplified mutant insert. No significant differences in expression levels were noted for the two AR189-919 plasmids, suggesting that the sequence flanking the second methionine is competent for initiation in the absence of sequence coding for the first methionine. To create pCMVhAR-M189A, methionine 189 was changed to alanine in full-length AR using PCR mutagenesis within an AfII/BstEII fragment which was ligated into pCMVhAR digested with the same enzymes. pCMVhAR156-919 was created by PCR mutagenesis by amplifying a BglII/BstEII fragment with an ATG nucleotide sequence placed prior to the sequence coding for residue 156 , followed by ligation into $\mathrm{pCMVhAR}$ digested with the same enzymes. pCMVhAR1-660 that expresses the AR $\mathrm{NH}_{2}$-terminal and DNA-binding regions and part of the hinge region was previously described (Simental et al. 1991). All regions amplified by PCR using Vent-polymerase (BioRad, Hercules, CA, USA) were verified by DNA sequencing.

\section{Immunoblot analysis}

Tissue and cell lysates were prepared in RIPA buffer containing protease inhibitors $(1 \%$ Triton $\mathrm{X}-100,1 \%$ sodium deoxycholate, $0 \cdot 1 \%$ sodium dodecyl sulfate, $0.15 \mathrm{M} \mathrm{NaCl}, 5 \mathrm{mM}$ EDTA, $50 \mathrm{mM}$ Tris- $\mathrm{HCl}$ pH 7.4 containing $0.5 \mathrm{mM}$ phenylmethylsulfonyl fluoride, $10 \mu \mathrm{M}$ pepstatin, $80 \mathrm{mg} / \mathrm{ml}$ leupeptin, $4 \mu \mathrm{M}$ aprotinin, $0.2 \mathrm{mM}$ sodium vanadate and $5 \mathrm{mM}$ benzamidine) with and without $1 \mu \mathrm{M}$ DHT as indicated in the figure legends. Tissue was homogenized $30 \mathrm{~s}$ on ice and incubated $30 \mathrm{~min}$ on ice followed by two centrifugations at $10000 \boldsymbol{g}$ for $20 \mathrm{~min}$ each. Cell lines (CWR-R1, LNCaP, LNCaP-C4-2, PC3, HFF-1 and $\mathrm{COS}$ ) were harvested from $10 \mathrm{~cm}$ dishes by scraping in PBS and centrifugation at $4{ }^{\circ} \mathrm{C}$ for $10 \mathrm{~min}$ to pellet the cells. RIPA with protease inhibitors with or without $1 \mu \mathrm{M}$ DHT was added to cell pellets and lysates were prepared by passing the cell suspensions through 22-gauge needles five times and trituration. Lysates were incubated on ice for $30 \mathrm{~min}$ followed by centrifugation at $10000 \boldsymbol{g}$ for $20 \mathrm{~min}$. Supernatants were used with or without freezing and storage at $-20{ }^{\circ} \mathrm{C}$ as indicated prior to separation on polyacrylamide gels containing SDS. Proteins were electroblotted to nitrocellulose membranes.

AR32 rabbit polyclonal antibody was raised against a peptide with sequence of human AR amino acid residues 9-28 (Quarmby et al. 1990). PG21 is a rabbit anti-peptide antibody raised 
against a peptide with sequence of $\mathrm{AR} \mathrm{NH}_{2}$ terminal residues 1-21 (Prins et al. 1991) (Research Diagnostics, Inc., Flanders, NJ, USA). AR52 rabbit polyclonal antibody was raised against a peptide with a sequence of human $\mathrm{AR}$ residues 544-558, which is $\mathrm{NH}_{2}$-terminal to the DNAbinding domain (Tan et al. 1988). AR32 and AR52 $\mathrm{IgG}$ fractions were prepared and used for immunoblotting at $1 \mu \mathrm{g} / \mathrm{ml}$. Mouse monoclonal antibody F39.4.1 (F39) was raised against a peptide with sequence derived from human $\mathrm{AR} \mathrm{NH}_{2}$-terminal residues 302-321 (Zegers et al. 1991) (Biogenex, San Ramon, CA, USA) and used for immunoblots at 1:10000 dilution. Rabbit polyclonal antibody C19 was raised against a peptide with sequence of human AR carboxyl-terminal residues 901-919 (Santa Cruz Biotechnology, Inc., Santa Cruz, CA, USA) and used for immunoblotting at $0 \cdot 2 \mu \mathrm{g} / \mathrm{ml}$. Secondary antibody (goat-anti-mouse $\mathrm{IgG}$ or goat anti-rabbit $\mathrm{IgG}$ conjugated to horseradish peroxidase (Amersham Corp., Arlington Heights, IL, USA)) was used for detection by enhanced chemiluminescence (Pierce, Rockford, IL, USA).

\section{RESULTS}

\section{$A R$ in cell lines and tissues}

Immunoblot analysis revealed a predominant $114 \mathrm{kDa}$ full-length $\mathrm{AR}$ in extracts of prostate cancer cell lines LNCaP, LNCaP-C4-2 and CWR-R1 (Fig. 1, lanes 1-3). Full-length AR was also evident in extracts of the CWR22 human prostate cancer xenograft propagated in nude mice (Wainstein et al. 1994, Nagabhushan et al. 1996, Tan et al. 1997) from both androgen-dependent tumors and recurrent tumors that arose after prolonged androgen deprivation by castration (Fig. 1, lanes 5-6). In addition, an $84 \mathrm{kDa}$ immunoreactive band was detected in the CWR-R1 cell line and CWR22 recurrent tumor extracts. There were only small amounts of the $84 \mathrm{kDa}$ form in $\mathrm{LNCaP}$ and $\mathrm{LNCaP}-\mathrm{C} 4-2$ cell lines and the androgen-dependent CWR22 tumor extracts (Fig. 1). Cultures of normal human foreskin fibroblasts showed the predominant $114 \mathrm{kDa} \mathrm{AR}$ with minor amounts of the smaller form (Fig. 1, lane 4). In contrast, immunoblot analysis of human $\mathrm{AR}$ transiently expressed in $\mathrm{PC} 3$ prostate cancer cells resulted in only the $114 \mathrm{kDa}$ band detected when DHT was included in the incubation media (Fig. 2A, lane 3). The increase in transiently expressed AR in PC3 in the presence of DHT most likely resulted from AR stabilization by androgen as we showed previously that AR is unstable in the absence of androgen (Kemppainen et al. 1992). AR

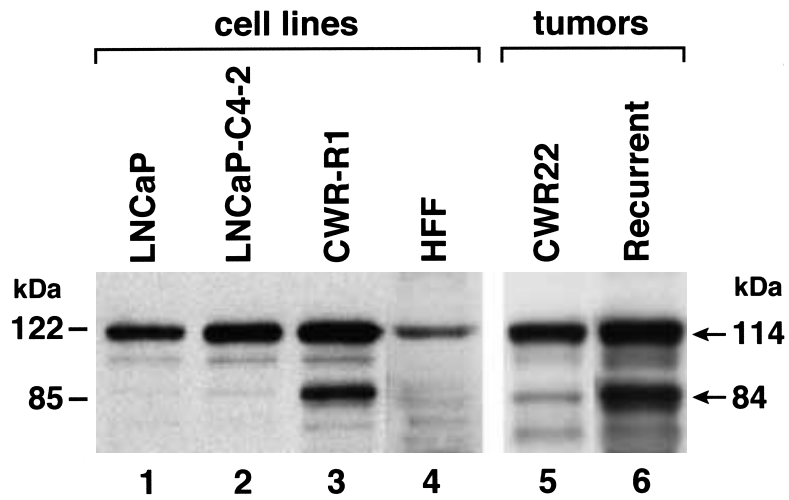

FIGURE 1. Immunoblot of endogenous AR from cell lines and CWR22 prostate tumor xenografts. Protein lysates $(10 \mu \mathrm{g} /$ lane) from LNCaP, LNCaP-C4-2, CWR-R1 and human foreskin fibroblast (HFF) cell lines and androgen-dependent (CWR22) and recurrent CWR22 tumors were analyzed on immunoblots using AR monoclonal antibody F39 (epitope 302-321). Lysates were prepared in RIPA buffer without DHT and analyzed after storage at $-20{ }^{\circ} \mathrm{C}$. Migration positions of the major AR bands at 114 (full-length) and $84 \mathrm{kDa}$ (arrows) and molecular mass markers are indicated. The data shown are representative of five separate immunoblots.

expression in COS cells in the presence of DHT revealed the $114 \mathrm{kDa}$ full-length $\mathrm{AR}$ and an additional $92 \mathrm{kDa}$ immunoreactive band (Fig. 2B, lane 1). No AR bands were detected in COS (not shown) or PC3 cells (Fig. 2A, lane 1, pCMV5) when transfected with the parent vector that lacked AR coding sequence as previously reported (Kaighn et al. 1979, Tilley et al. 1990). Since the electrophoretic migration of both smaller forms was similar to that of the previously described $87 \mathrm{kDa}$ AR-A (Wilson \& McPhaul 1994, 1996, Gao \& McPhaul 1998), we investigated their origin and domain composition.

Anti-peptide antibodies that react with specific epitopes within the AR sequence were used on immunoblots to detect the presence of the different AR domains. These included $\mathrm{NH}_{2}$-terminal antibodies PG21 (epitope at amino acid residues 1-21) (Prins et al. 1991), AR32 (epitope 9-28) (Quarmby et al. 1990), F39 (epitope 302-321) (Zegers et al. 1991) and AR52 (epitope 544-558) (Tan et al. 1988), as well as carboxyl-terminal antibody C19 (epitope 901-919) (Fig. 3). We also addressed whether the smaller AR forms observed above resulted from initiation at the second methionine at residue 189 in a manner analogous to that of PR-A (Kastner et al. 1990b) and as previously suggested for AR-A (Wilson \& McPhaul 1994). Two different AR189-919 mutants (a and b) were created so that 
A. PC3 cells

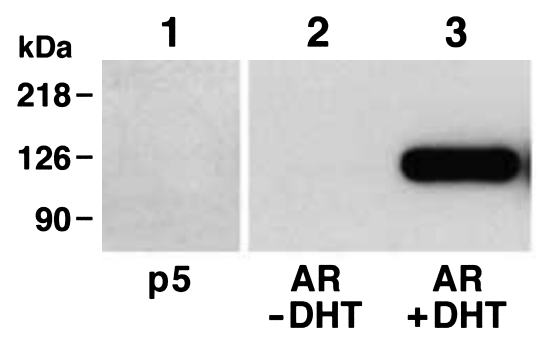

B. Cos cells

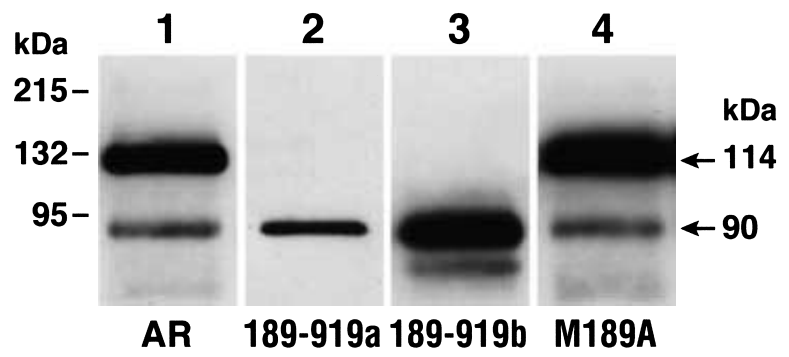

FIGURE 2. Immunoblots of $\mathrm{AR}$ and $\mathrm{AR}$ mutants transiently expressed in PC3 and COS cells. (A) Human prostate cancer PC3 cells were transfected with empty parent vector pCMV5 (p5) or with wild-type human AR expression vector pCMVhAR (AR). PC3 cells were incubated in the absence (lane 2) and presence (lane 3 ) of $10 \mathrm{nM}$ DHT for $24 \mathrm{~h}$ prior to harvest. Protein lysates were prepared in RIPA buffer containing $1 \mu \mathrm{M}$ DHT and $10 \mu \mathrm{g}$ protein samples were analyzed on immunoblots using AR polyclonal antibody C19 (epitope 901-919). (B) COS cells were transfected with the following AR expression vectors: wild-type pCMVhAR (AR, lane 1), pCMVhAR189-919a in which amino acid residues 1-171 were deleted to retain the flanking sequence of methionine 189 (lane 2), pCMVhAR189-919b where 28 nucleotides of sequence derived from the $5^{\prime}$ flanking sequence of the first methionine were inserted before the second methionine at residues 189 (lane 3), and pCMVhARM189A, in which methionine 189 was changed to alanine in fulllength pCMVhAR (lane 4). Transfected COS cells were incubated with $500 \mathrm{nM}$ DHT $24 \mathrm{~h}$ prior to harvest. Lysates were prepared in RIPA buffer containing $1 \mu \mathrm{M}$ DHT and $10 \mu \mathrm{g}$ samples were analyzed on immunoblots using AR polyclonal antibody C19 (epitope 901-919). Migration positions of the major AR bands (arrows on right) and molecular mass markers (left) are indicated. The data are representative of two to four separate experiments.

the first $\mathrm{NH}_{2}$-terminal 188 amino acid residues were not expressed (Fig. 3, AR189-919). The coding sequence in pCMVhAR for residues 1-171 was deleted by restriction enzyme digestion (BglII/ AfIII) in AR189-919a so that the wild-type sequence flanking methionine 189 was retained. For AR189-919b we used PCR mutagenesis to insert

www.endocrinology.org the 28 nucleotide sequence $5^{\prime}$ of the first methionine codon in front of the codon for the second methionine at residue 189. Expression of both recombinant AR189-919a and b mutants resulted in $90 \mathrm{kDa}$ bands that were indistinguishable or slightly smaller than the fragment observed when full-length AR was expressed in COS cells (Fig. 2B, lanes 1-3). The results indicate that under these expression conditions, the naturally occurring flanking sequence of the second methionine is sufficient for robust initiation of a $90 \mathrm{kDa}$ truncated $\mathrm{AR}$ in a construct in which the coding sequence of the first methionine and subsequent amino acids was deleted.

Data from the AR189-919 mutants raised the possibility that the smaller AR bands observed in cell and tissue extracts and in transient expression studies resulted from initiation at methionine 189 . To address this, a full-length AR expression construct was created in which the second methionine at residue 189 was replaced by alanine. Surprisingly, expression of AR-M189A yielded a similar proportion of full-length $114 \mathrm{kDa} A R$ and the $92 \mathrm{kDa}$ immunoreactive band (Fig. 2B, lane 4). The results indicate that the smaller form did not result from initiation at the second methionine.

\section{Analysis of AR fragments using AR-specific anti-peptide antibodies}

Peptide-specific AR antibodies were used to probe immunoblots to establish whether the smaller AR forms detected in cell and tumor extracts resulted from the absence of the $\mathrm{NH}_{2}$ - or carboxyl-terminal region. The positions of the peptides used in raising the antibodies are shown relative to the AR sequence (Fig. 3). The $84 \mathrm{kDa}$ AR band present in CWR-R1 cell extracts was detected using AR $\mathrm{NH}_{2}$-terminal antibodies AR32 and PG21, but was not detected with AR carboxyl-terminal antibody C19 (Fig. 4). The $84 \mathrm{kDa}$ band from the CWR-R1 cell extracts was also detected with $\mathrm{NH}_{2}$-terminal domain antibodies F39 (see Fig. 1) and AR52 (not shown). Consistent with these results, the $84 \mathrm{kDa}$ band comigrated with AR deletion mutant AR1-660 (Fig. 4, last lane) that comprises the $\mathrm{AR} \mathrm{NH}_{2}$ terminal, DNA-binding domain and hinge regions and lacks the carboxyl-terminal ligand-binding domain (see Fig. 3). Thus the $84 \mathrm{kDa}$ form observed in the prostate cancer cell lines and tumors lacks the carboxyl-terminal ligand-binding domain. Based on previous transient transfection studies using AR1-660 (Simental et al. 1991), the presence of this $84 \mathrm{kDa}$ fragment in vivo would result in constitutive AR transcriptional activity.

In contrast, the $92 \mathrm{kDa}$ band evident after expression of AR in COS cells was not detected 


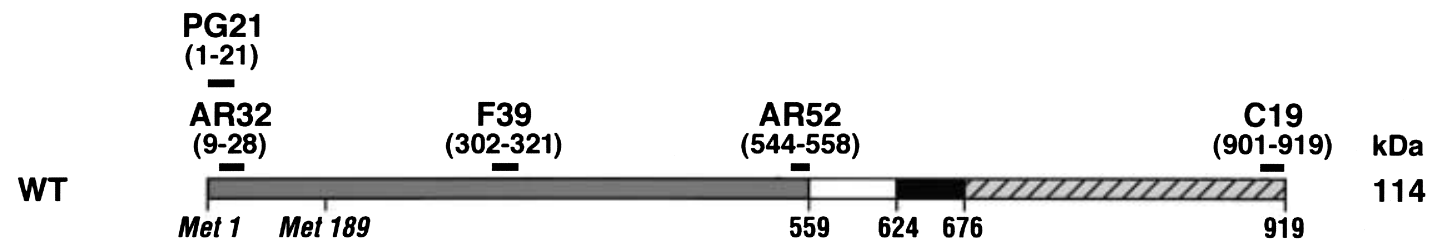

AR 1-660

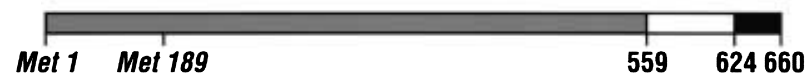

84

AR 156-919
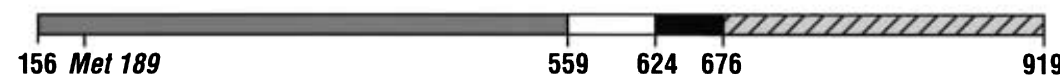

92

AR 189-919

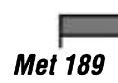

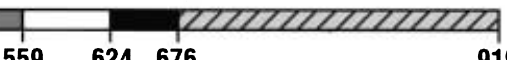

90

FIGURE 3. Schematic diagram of wild-type and mutant human AR coding regions, the position of antibody epitopes and apparent molecular masses. Regions from which peptides were designed and used to produce anti-peptide AR antibodies PG21, AR32, F39, AR52 and C19 are indicated above the diagram. Diagrams of the coding regions are shown for full-length wild-type AR amino acid residues 1-919 (WT), AR1-660 comprising the $\mathrm{NH}_{2}$-terminal, DNA-binding domain and hinge region amino acid residues 1-660, AR156-919 in which there is deletion of 155 residues of the $\mathrm{NH}_{2}$-terminal sequence, representing a caspase-3 cleavage site, and AR189-919 designed to initiate at the second methionine at residue 189. AR189-919a and AR189-919b were designed as described in Fig. 2 legend and in Materials and Methods. Positions of the first (Met 1) and second (Met 189) methionines are indicated as well as the amino acid residue boundaries of the $\mathrm{NH}_{2}$-terminal (gray), DNA-binding domain (white), hinge region (black), steroid-binding domain (hatched) and apparent molecular masses $(\mathrm{kDa})$ determined by SDS gel electrophoresis.

by $\mathrm{AR} \mathrm{NH}_{2}$-terminal antibody $\mathrm{AR} 32$ but was recognized by antibodies $\mathrm{F} 39, \mathrm{AR} 52$ and $\mathrm{C} 19$ (Fig. 5A). An additional minor band was detected by the F39 antibody forming a doublet of the lower band (Fig. 5A, lane 2) and likely resulted from the greater sensitivity of the F39 antibody. The results are consistent with observations above (see Fig. 2B) that the $92 \mathrm{kDa}$ AR fragment is similar to the expressed mutant AR189-919 that was designed to initiate at the second methionine. The $92 \mathrm{kDa}$ fragment therefore lacks slightly fewer than 190 amino acid residues from the $\mathrm{AR} \mathrm{NH}_{2}$-terminus

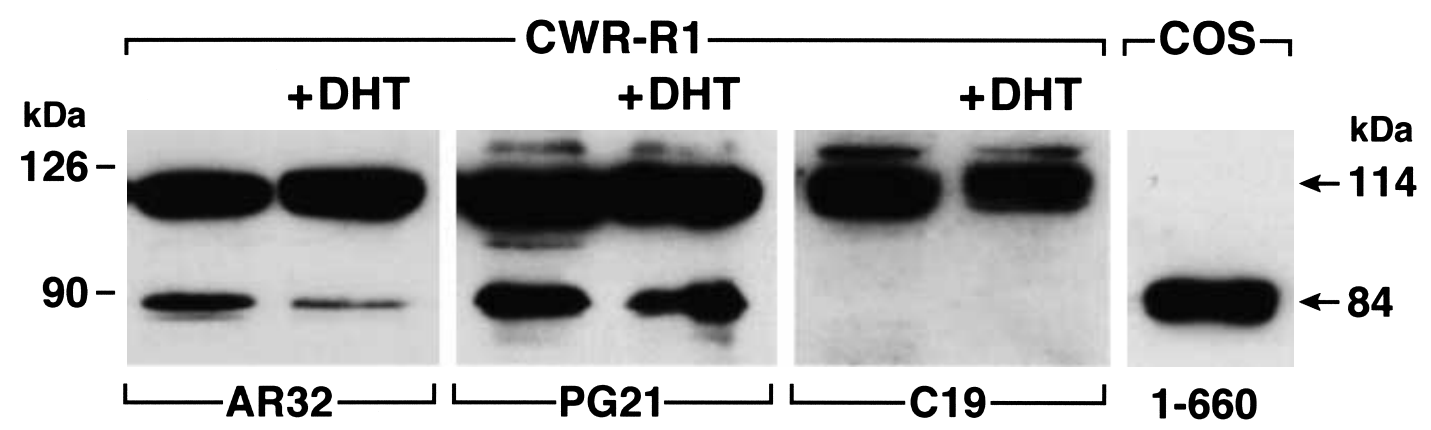

FIGURE 4. Immunoblots of endogenous AR from the CWR-R1 human prostate cancer cell line and the AR1-660 deletion mutant expressed in COS cells. CWR-R1 cells were cultured in the absence and presence of $10 \mathrm{nM}$ DHT as indicated for $48 \mathrm{~h}$ prior to harvest. COS cells were transfected as described in Materials and Methods with pCMVhAR1-660, which codes for the $\mathrm{NH}_{2}$-terminal, DNA-binding domain and hinge regions (see Fig. 3). Immunoblots of $10 \mu \mathrm{g}$ protein extracts prepared in the presence of $1 \mu \mathrm{M}$ DHT were analyzed using anti-peptide antibodies AR32 (epitope 9-28), PG21 (epitope 1-21) and C19 (epitope 901-919) as indicated. AR32 antibody was used for AR1-660. Positions of the major AR bands (arrows on right), molecular mass markers (left) and the antibodies used for detection are indicated. The data are representative of three separate experiments. 

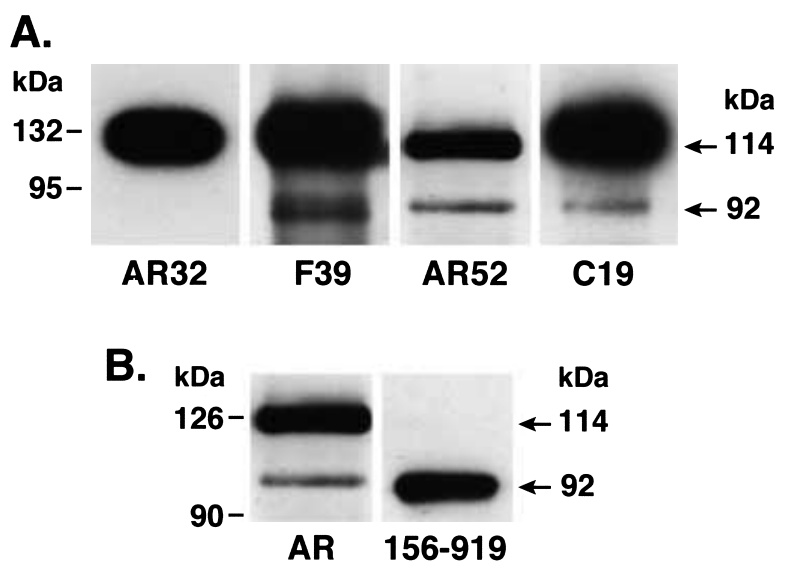

FIGURE 5. Immunoblots of wild-type AR and deletion mutant AR156-919 transiently expressed in COS cells. Protein samples were analyzed from cells incubated in the presence of $500 \mathrm{nM}$ DHT $24 \mathrm{~h}$ prior to harvest in RIPA buffer containing $1 \mu \mathrm{M}$ DHT. (A) COS cell extracts $(10 \mu \mathrm{g}$ protein) after expression of full-length pCMVhAR were analyzed on immunoblots using AR antibodies AR32 (epitope 9-28), F39 (epitope 302-321), AR52 (epitope 544-558) and C19 (epitope 901-919) as indicated. (B) Full-length pCMVhAR (AR) and deletion fragment pCMVhAR156-919 were transiently expressed in COS cells and cell extracts $(10 \mu \mathrm{g}$ protein) were analyzed on immunoblots using antibody C19 (epitope 901-919). Positions of the major AR bands (arrows on right) and molecular mass markers (left) are indicated. The data are representative of two or three separate experiments.

and, as shown above, does not result from initiation at methionine 189 . The results indicate that, depending on the cell type, AR forms that migrate like the previously described AR-A (Wilson \& McPhaul 1994, 1996, Gao \& McPhaul 1998) lack either the $\mathrm{NH}_{2}$ - or carboxyl-terminal region.

\section{In vitro proteolytic degradation}

To investigate whether the smaller AR forms result from in vitro proteolytic degradation during tissue or cell extraction or sample storage, extraction conditions were modified and frozen extracts compared with freshly prepared samples. When CWR-R1 cells were extracted in the same RIPA buffer so as to maintain $4{ }^{\circ} \mathrm{C}$ in the presence of $1 \mu \mathrm{M}$ DHT and extracts immediately analyzed on immunoblots, only the single full-length $114 \mathrm{kDa}$ AR band was observed (Fig. 6, lane 1). Similar analysis of $\mathrm{LNCaP}$ and $\mathrm{LNCaP}-\mathrm{C} 4-2$ cells also revealed the full-length $\mathrm{AR}$ and almost undetectable bands for the smaller forms (Fig. 6, lanes 3 and 5). If the same extracts were stored frozen overnight

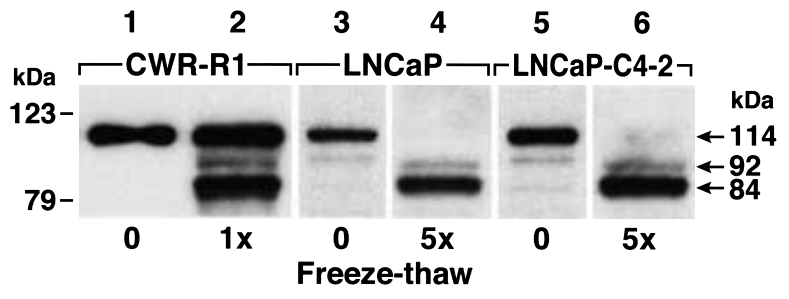

FIGURE 6. Immunoblot of endogenous AR from CWR-R1, LNCaP and LNCaP-C4-2 cell lines. CWR-R1 (lane 1), LNCaP (lane 3) and LNCaP-C4-2 cells (lane 5) were extracted in ice-cold PBS on ice in RIPA buffer containing $1 \mu \mathrm{M}$ DHT and samples were analyzed immediately on gels. In lane 2, a parallel sample of CWR-R1 extract was prepared as in lane 1 but was stored frozen overnight at $-20{ }^{\circ} \mathrm{C}$ prior to analysis (lane $2,1 \times$ ). Lysates of $\mathrm{LNCaP}$ cells (lane 4) and LNCaP-C4-2 cells (lane 6) were stored frozen for 3 weeks at $-20{ }^{\circ} \mathrm{C}$ during which time they were thawed and frozen five times $(5 \times)$ prior to analysis. The immunoblot was probed with F39 monoclonal antibody (epitope 901-919). Positions of the major AR bands (arrows on right) and molecular mass markers (left) are indicated. The data shown are representative of two or three separate experiments.

and reanalyzed, the $84 \mathrm{kDa}$ form was prominent with a minor $92 \mathrm{kDa}$ band (Fig. 6, lane 2). After repeated freezing and thawing and storage, shown for $\mathrm{LNCaP}$ and LNCaP-C4-2 extracts (Fig. 6, lanes 4 and 6), the $84 \mathrm{kDa}$ fragment was predominant with a minor $92 \mathrm{kDa}$ band, whereas the full-length $114 \mathrm{kDa}$ AR was not detected. Similar results were obtained after storage of the CWR22 cell line extracts (data not shown). DHT in the extraction media increased the recovery of full-length $114 \mathrm{kDa}$ $\mathrm{AR}$ and reduced the amount of the smaller forms (data not shown); however, the presence of a cocktail of standard protease inhibitors which was present in all of the studies (see Materials and Methods) was not sufficient to block the in vitro breakdown of AR when samples were stored and later analyzed. Similar extraction and immunoblot studies of AR expression in COS cells indicated that the $92 \mathrm{kDa}$ band results from proteolytic cleavage during extraction.

An in vitro caspase- 3 cleavage site was reported at human AR aspartic acid residue 146 (Ellerby et al. 1999). Because of the polymorphic length of the $\mathrm{NH}_{2}$-terminal glutamine repeat (Choong \& Wilson 1998), numbering of AR amino acid residues can vary. Based on the $A R$ residue numbering of Lubahn et al. (1988) which is used by the AR mutation database (Gottlieb et al. 1998), and considering the consensus sequences for caspase cleavage (Earnshaw et al. 1999), caspase-3 cleavage would occur between human AR aspartic acid 
residue 155 and serine 156 . To determine whether caspase cleavage could account for the $92 \mathrm{kDa}$ fragment, we compared the migration of AR deletion mutant AR156-919 (see Fig. 3) with AR fragments observed in the COS cell extracts. Migration of the AR156-919 fragment, which simulates the AR fragment resulting from a proposed caspase cleavage site, was at $92 \mathrm{kDa}$ (Fig. 5B) and thus it comigrated with the $92 \mathrm{kDa}$ fragments described above and migrated slightly faster than the AR fragments that initiate at the second methionine. The results suggest that during preparation and analysis, smaller forms of AR evident in cell and tissue extracts result from proteolytic cleavage of the $\mathrm{NH}_{2}$ - or carboxylterminal domain, resulting in fragments with electrophoretic migration similar to that of the previously described AR-A.

\section{DISCUSSION}

We investigated whether AR occurs in physiologically relevant smaller forms as described previously for PR (Horwitz \& Alexander 1983, Krett et al. 1988, Kastner et al. 1990b). The PR gene was shown to initiate at the first or second methionine, depending on promoter usage (Kastner et al. 1990b). A short $87 \mathrm{kDa}$ form designated AR-A was also reported to be physiologically significant, but in contrast to PR, the smaller form of AR was detected in quantities only about $10 \%$ of those of the full-length $114 \mathrm{kDa}$ AR (Wilson \& McPhaul 1994, 1996, Gao \& McPhaul 1998). We observed the $114 \mathrm{kDa}$ full-length $\mathrm{AR}$ and an $84 \mathrm{kDa} \mathrm{AR}$ fragment in extracts from $\mathrm{LNCaP}$ and CWR22 human prostate cancer cell lines, from xenograft tumor samples and from normal human foreskin fibroblast cultures. Peptide-specific antibodies indicated that the smaller $84 \mathrm{kDa}$ AR fragment lacked the carboxyl-terminal ligand-binding domain. Full-length AR transiently expressed in COS cells revealed the $114 \mathrm{kDa} \mathrm{AR}$ and a $92 \mathrm{kDa}$ form that migrated similarly to AR mutants that were created to initiate at the second methionine. However, when the second methionine was changed to alanine by PCR mutagenesis in the full-length $\mathrm{AR}$ expression vector, the $92 \mathrm{kDa}$ form was again observed, indicating that the smaller form did not result from initiation at the second methionine. Peptide-specific AR antibodies provided evidence that the $92 \mathrm{kDa}$ form lacked part of the $\mathrm{NH}_{2}$ terminal region as suggested previously for AR-A (Wilson \& McPhaul 1994, 1996, Gao \& McPhaul 1998) and could be accounted for by in vitro cleavage at a caspase- 3 site. Both the 84 and $92 \mathrm{kDa}$ forms were eliminated by the use of extraction and storage conditions that minimized in vitro proteolytic degradation, indicating that the putative A form of $\mathrm{AR}$ most likely results from in vitro proteolytic cleavage of the carboxyl- or $\mathrm{NH}_{2}-$ terminal regions during extraction. While it cannot be definitively ruled out that very small amounts of AR-A form through alternative pathways, the data suggest that differences in intensity of AR-A previously reported in different tissues (Gao \& McPhaul 1998) reflect tissue- and cell-specific differences in protease activity during extraction and storage of protein extracts rather than differences in expression of multiple AR forms. Absence of the smaller forms after AR expression in prostate cancer PC3 cells suggests that PC3 cells have less protease activity during cell extraction.

The consensus Kozak initiation sequence for optimal translation initiation is A/GNNATGGNN (Kozak 1999), where $\mathrm{N}$ can be any nucleotide. The first translation initiation sequence for human, mouse and rat AR $\left(\mathrm{A}^{-3} \mathrm{GGATGG}^{+4} \mathrm{AA} / \mathrm{G}\right)$ conforms to this consensus sequence, whereas sequence flanking the second methionine does not $\left(\mathrm{A}^{-3} \mathrm{CCATGC}^{+4} \mathrm{AA}\right.$ ) (Table 1). According to a leaky scanning theory proposed by Kozak (1999), translation does not initiate from a second weaker start site of a single transcript when the first start site conforms to the consensus sequence. Initiation at a second methionine can occur, however, when the sequence flanking the second methionine more closely adheres to the consensus sequence than does the first initiation start site, as recently reported for GR (Yudt \& Cidlowski 2001). In support of the model, mutagenesis to create a consensus translation initiation sequence for the first ATG in GR abolished expression from the second ATG site (Yudt \& Cidlowski 2001). The leaky scanning mechanism is also supported by the inability of chicken and human PR-A to be translated from a single PR-B transcript (Kastner et al. 1990a). The first translation initiation site in human and chicken PR-B conforms to the Kozak consensus translation initiation sequence better than the second start site sequence (Table 1). Thus, although transient expression studies presented here indicated that the second AR methionine 189 could initiate translation when the coding sequence for the first methionine was deleted, the leaky scanning hypothesis predicts that the presence of a consensus translation initiation sequence at the first methionine in AR inhibits initiation at the second methionine. The results of the present study support the concept that smaller AR forms do not result from initiation at the second methionine.

While our studies cannot rule out the possibility of a low abundance alternative splice variant for AR, 
TABLE 1. Nucleotide sequences for the consensus Kozak translation initiation sequence (Kozak 1999), and for the first and second possible translation initiation start sites for the human AR (Lubahn et al. 1988), mouse AR (Charest et al. 1991), rat AR ('Tan et al. 1988), human PR (Kastner et al. 1990a,b), chicken PR (Conneely et al. 1987, Gronemeyer et al. 1987) and human GR (Hollenberg et al. 1985)

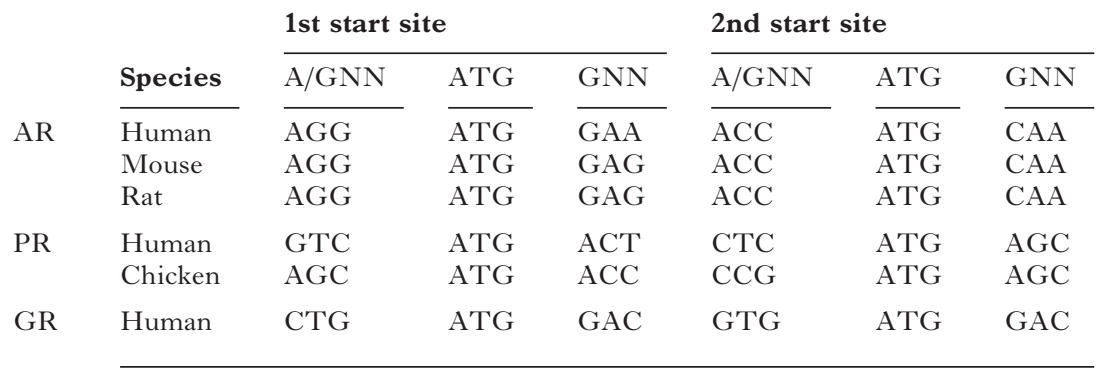

the data are consistent with AR being highly susceptible to proteolytic cleavage. Further analysis of the transcriptional activity of the smaller AR forms was therefore not pursued, although the results of cotransfection assays indicated that the $\mathrm{NH}_{2}$-terminally truncated mutant AR189-919 lacked dominant negative activity in contrast to the dominant negative effect of PR-A on PR-B activity (Tung et al. 1993, Vegeto et al. 1993). A constitutively active AR-A form that lacks the carboxyl-terminal ligand-binding domain in CWR22 and LNCaP prostate cancer cell lines therefore cannot explain the increased expression of androgen-regulated genes observed in recurrent tumor models (Gregory et al. 1998), which could result from p160 coactivator overexpression (Gregory et al. 2001a). The data similarly argue against an $\mathrm{NH}_{2}$-terminally deleted form as previously postulated for AR-A, which could be accounted for by in vitro caspase-3 cleavage. Because cleavage by caspase- 3 removes the $\mathrm{NH}_{2}$ terminal ${ }^{23} \mathrm{FQNLF}^{27}$ sequence that interacts with AF2 in the ligand-binding domain (He et al. 2000), it was important to establish whether this occurs in vivo or in vitro. In vivo cleavage could allow AF2 in the ligand-binding domain to more efficiently recruit p160 coactivators (He et al. 2000).

AR differs from other steroid receptors in having a single copy gene on the $\mathrm{X}$ chromosome, and in males, a single allele. AR apparently also appears to differ from other steroid receptors by occurring only in its full-length form when other receptors have multiple genes or forms. Retention of the entire $\mathrm{NH}_{2}$-terminal domain is required for the androgeninduced $\mathrm{AR} \mathrm{NH}_{2}-$ and carboxyl-terminal interaction (Langley et al. 1995, 1998). The androgen insensitivity syndrome highlights the singular importance of the AR gene in male sexual development (Quigley et al. 1995) and the essential role of an ever increasing number of amino acid residues in the DNA- and steroid-binding domains. Substitution mutations of more than 200 amino acids cause different degrees of androgen resistance (Gottlieb et al. 1998). The absence, with few exceptions (Choong et al. 1996, Ghadessy et al. 1999), of single missense mutations in the $\mathrm{NH}_{2}$-terminal domain associated with androgen insensitivity is striking, considering the critical role of this region in AR transcriptional activity. The studies presented here support the requirement for full-length AR expression in vivo.

\section{ACKNOWLEDGEMENTS}

We thank Raymond T Johnson, Nathanael D Pelton, Natalie T Bowen, John T Minges and K Michelle Cobb for technical assistance, and Frank S French for critical reading of the manuscript. The work was supported by grants P01 CA77739 from NCI and HD16910 from NICHD, by cooperative agreement U54-HD35041 as part of the Specialized Cooperative Centers Program in Reproductive Research of NIH, by the US Army Medical Research and Material Command grant DAMD1700-1-0094, and by the International Training and Research in Population and Health Program supported by the Fogarty International Center and NICHD, NIH.

\section{REFERENCES}

Chang C, Kokontis J \& Liao S 1988 Molecular cloning of human and rat complementary DNA encoding androgen receptors. Science 240 324-326.

Charest NJ, Zhou ZX, Lubahn DB, Olsen KL, Wilson EM \& French FS 1991 A frameshift mutation destabilizes androgen receptor messenger RNA in the Tfm mouse. Molecular Endocrinology 5 573-581. 
Choong CS \& Wilson EM 1998 Trinucleotide repeats in the human AR: a molecular basis for disease. Fournal of Molecular Endocrinology 21 235-257.

Choong CS, Quigley CA, French FS \& Wilson EM 1996 A novel missense mutation in the amino-terminal domain of the human androgen receptor gene in a family with partial androgen insensitivity syndrome causes reduced efficiency of protein translation. Fournal of Clinical Investigation $\mathbf{9 8}$ 1423-1431.

Clemm DL, Sherman L, Boonyaratanakornkit V, Schrader WT, Weigel NL \& Edwards DP 2000 Differential hormone dependent phosphorylation of progesterone receptor $\mathrm{A}$ and $\mathrm{B}$ forms revealed by a phosphoserine site specific monoclonal antibody. Molecular Endocrinology 14 52-65.

Conneely OM, Dobson ADW, Tsai MJ, Beattie WG, Toft DO, Huckaby CS, Zarucki T, Schrader WT \& O'Malley BW 1987 Sequence and expression of a functional chicken progesterone receptor. Molecular Endocrinology 1 517-525.

De Bellis A, Quigley CA, Marschke KB, El-Awady MK, Lane MV, Smith EP, Sar M, Wilson EM \& French FS 1994 Characterization of mutant androgen receptors causing partial androgen insensitivity syndrome. Fournal of Clinical Endocrinology and Metabolism 78 513-522.

Earnshaw WC, Martins LM \& Kaufmann SH 1999 Mammalian caspases: structure, activation, substrates and functions during apoptosis. Annual Review of Biochemistry 68 383-424.

Ellerby LM, Hackam AS, Propp SS, Ellerby HM, Rabizadeh S, Cashman NR, Trifiro MA, Pinsky L, Wellington CL, Salvesen GS, Hayden MR \& Bredesen DE 1999 Kennedy's disease: caspase cleavage of the androgen receptor is a crucial event in cytotoxicity. Fournal of Neurochemistry 72 185-195.

Feil PD, Clarke CL \& Satyaswaroop PG 1988 Progesterone receptor structure and protease activity in primary human endometrial carcinoma. Cancer Research 48 1143-1149.

Gao T \& McPhaul MJ 1998 Functional activities of the A and $\mathrm{B}$ forms of the human androgen receptor in response to androgen receptor agonists and antagonists. Molecular Endocrinology 12 654-663.

Ghadessy FJ, Lim J, Abdullah AA, Panet-Raymond V, Choo CK, Lumbroso R, Tut TG, Gottlieb B, Pinsky L, Trifiro MA \& Yong EL 1999 Oligospermic infertility associated with an androgen receptor mutation that disrupts interdomain and coactivator (TIF2) interactions. Fournal of Clinical Investigation 103 1517-1525.

Gottlieb B, Lehvaslaiho H, Beitel LK, Lumbroso R, Pinsky L \& Trifiro M 1998 The androgen receptor gene mutations database. Nucleic Acids Research 26 234-238.

Gregory CW, Hamil KG, Kim D, Hall SH, Pretlow TG, Mohler JL \& French FS 1998 Androgen receptor expression in androgen independent prostate cancer is associated with increased expression of androgen regulated genes. Cancer Research 58 5718-5724.

Gregory CW, He B, Johnson RT, Ford OH, Mohler JL, French FS \& Wilson EM $2001 a$ A mechanism for androgen receptor mediated prostate cancer recurrence after androgen deprivation therapy. Cancer Research 61 4315-4319.

Gregory CW, Johnson RT, Mohler JL, French FS \& Wilson EM $2001 b$ Androgen receptor stabilization in recurrent prostate cancer is associated with hypersensitivity to low androgen. Cancer Research 61 2892-2898.

Gronemeyer H, Turcotte B, Quirin-Stricker C, Bocquel MT, Meyer ME, Krozowski Z, Jeltsch JM, Lerouge T, Garnier JM \& Chambon P 1987 The chicken progesterone receptor: sequence, expression and functional analysis. EMBO fournal 6 3985-3994.

He B, Kemppainen JA, Voegel JJ, Gronemeyer H, Wilson EM 1999 Activation function 2 in the human androgen receptor ligand binding domain mediates interdomain communication with the $\mathrm{NH}_{2}$-terminal domain. Fournal of Biological Chemistry 274 37219-37225.

He B, Kemppainen JA \& Wilson EM 2000 FXXLF and WxxLF sequences mediate the $\mathrm{NH}_{2}$-terminal interaction with the ligand binding domain of the androgen receptor. Fournal of Biological Chemistry 275 22986-22994.

He B, Bowen NT, Minges JT \& Wilson EM 2001 Androgeninduced $\mathrm{NH}_{2}$ - and carboxyl-terminal interaction inhibits p160 coactivator recruitment by activation function 2 . Fournal of Biological Chemistry (In Press).

Hollenberg SM, Weinberger C, Ong ES, Cerelli G, Oro A, Lebo R, Thompson EB, Rosenfeld MG \& Evans RM 1985 Primary structure and expression of a functional human glucocorticoid receptor cDNA. Nature 18 635-641.

Horoszewicz JS, Leong SS, Kawinski E, Karr JP, Rosenthal H, Chu TM, Mirand EA \& Murphy GP 1983 LNCaP model of human prostatic carcinoma. Cancer Research 43 1809-1818.

Horwitz KB \& Alexander PS 1983 In situ photolinked nuclear progesterone receptors of human breast cancer cells: subunit molecular weights after transformation and translocation. Endocrinology 113 2195-2201.

Ikeuchi T, Todo T, Kobayashi T \& Nagahama Y 1999 cDNA cloning of a novel androgen receptor subtype. Fournal of Biological Chemistry 274 25205-25209.

Kaighn ME, Narayan KS, Ohnuki Y, Lechner JF \& Jones LW 1979 Establishment and characterization of a human carcinoma cell line (PC-3). Investigative Urology 17 16-23.

Kastner P, Bocquel MT, Turcotte B, Garnier JM, Horwitz KB, Chambon P, Gronemeyer H $1990 a$ Transient expression of human and chicken progesterone receptors does not support alternative translational initiation from a single mRNA as the mechanism generating two receptor isoforms. Fournal of Biological Chemistry 265 12163-12167.

Kastner P, Krust A, Turcotte B, Stropp U, Tora L, Gronemeyer H \& Chambon P $1990 b$ Two distinct estrogen regulated promoters generate transcripts encoding the two functionally different human progesterone receptor forms A and B. EMBO Fournal 9 1603-1614.

Kato J, Hisata S, Nozawa A \& Mouri N 1993 The ontogeny of gene expression of progestin receptors in the female rat brain. Fournal of Steroid Biochemistry and Molecular Biology 47 173-182.

Kemppainen JA, Lane MV, Sar M \& Wilson EM 1992 Androgen receptor phosphorylation, turnover, nuclear transport and transcriptional activation: specificity for steroids and antihormones. Fournal of Biological Chemistry $267968-974$.

Kozak M 1999 Initiation of translation in prokaryotes and eukaryotes. Gene 234 187-208.

Krett NL, Wei LL, Francis MD, Nordeen SK, Gordon DF, Wood WM \& Horwitz KB 1988 Human progesterone A-receptors can be synthesized intracellularly and are biologically functional. Biochemical and Biophysical Research Communications 157 278-285.

Kuiper GGJM, Enmark E, Pelto-Huikko M, Nilsson S \& Gustafsson JA 1996 Cloning of a novel estrogen receptor expressed in rat prostate and ovary. PNAS 93 5925-5930.

Langley E, Zhou ZX \& Wilson EM 1995 Evidence for an antiparallel orientation of the ligand activated human androgen receptor dimer. Fournal of Biological Chemistry 270 29983-29990.

Langley E, Kemppainen JA \& Wilson EM 1998 Intermolecular $\mathrm{NH}_{2}$-/carboxyl-terminal interactions in androgen receptor dimerization revealed by mutations that cause androgen insensitivity. Fournal of Biological Chemistry 273 92-101.

Lim CS, Baumann CT, Htun H, Xian W, Irie M, Smith CL \& Hager GL 1999 Differential localization and activity of the A 
and $\mathrm{B}$ forms of the human progesterone receptor using green fluorescent protein chimeras. Molecular Endocrinology 13 366-375.

Lubahn DB, Joseph DR, Sar M, Tan JA, Higgs HN, Larson RE, French FS \& Wilson EM 1988 The human androgen receptor: complementary DNA cloning, sequence analysis and gene expression in prostate. Molecular Endocrinology 2 $1265-1275$.

Mangal RK, Wiehle RD, Poindexter AN \& Weigel NL 1997 Differential expression of uterine progesterone receptor forms A and B during the menstrual cycle. Fournal of Steroid Biochemistry and Molecular Biology 63 195-202.

Mosselman S, Polman J \& Dijkema R 1996 ER $\beta$ : identification and characterization of a novel human estrogen receptor. FEBS Letters 392 49-53.

Nagabhushan M, Miller CM, Pretlow TP, Giaconia JM, Edgehouse NL, Schwartz S, Kung HJ, deVere White RW, Gumerlock PH, Resnick MI, Amini SB \& Pretlow TG 1996 CWR22: the first human prostate cancer xenograft with strongly androgen dependent and relapsed strains both in vivo and in soft agar. Cancer Research 56 3042-3046.

Oakley RH, Sar M \& Cidlowski JA 1996 The human glucocorticoid receptor isoform: expression, biochemical properties and putative function. Fournal of Biological Chemistry 271 9550-9559.

Pietrzkowski Z, Mulholland G, Gomella L, Jameson BA, Wernicke D \& Baserga R 1993 Inhibition of growth of prostatic cancer cell lines by peptide analogues of insulin-like growth factor 1. Cancer Research 53 1102-1106.

Presnell SC, Borchert KM, Glover WJ, Gregory CW, Mohler JL \& Smith GJ 1998 Isolation and characterization of propagable cell lines (HUNC) from the androgen sensitive Dunning R3327H rat prostatic adenocarcinoma. Carcinogenesis 19 585-590.

Prins GS, Birch L \& Greene GL 1991 Androgen receptor localization in different cell types of the adult rat prostate. Endocrinology 129 3187-3199.

Quarmby VE, Kemppainen JA, Sar M, Lubahn DB, French FS \& Wilson EM 1990 Expression of recombinant androgen receptor in cultured mammalian cells. Molecular Endocrinology 4 1399-1407.

Quigley CA, De Bellis A, Marschke KB, El-Awady MK, Wilson EM \& French FS 1995 Androgen receptor defects: historical, clinical and molecular perspectives. Endocrine Reviews 16 271-321.

Sartorius CA, Groshong SD, Miller LA, Powell RL, Tung L, Takimoto GS \& Horwitz KB 1994 New T47D breast cancer cell lines for the independent study of progesterone B and A receptors: only antiprogestin occupied $\mathrm{B}$ receptors are switched to transcriptional agonists by cAMP. Cancer Research 54 3868-3877.

Simental JA, Sar M, Lane MV, French FS \& Wilson EM 1991 Transcriptional activation and nuclear targeting signals of the human androgen receptor. Fournal of Biological Chemistry $266510-518$.

Spelsberg TC \& Halberg F 1980 Circannual rhythms in steroid receptor concentration and nuclear binding in the chick oviduct. Endocrinology 107 1234-1244.

Takeo J \& Yamashita S 1999 Two distinct isoforms of cDNA encoding rainbow trout androgen receptors. Fournal of Biological Chemistry $2745674-5680$.

Tan JA, Joseph DR, Quarmby VE, Lubahn DB, Sar M, French FS \& Wilson EM 1988 The rat androgen receptor: primary structure, autoregulation of its messenger RNA and immunocytochemical localization of the receptor protein. Molecular Endocrinology 2 1276-1285.

Tan JA, Sharief Y, Hamil KG, Gregory CW, Zang DY, Sar M, Gumerlock PH, deVere White RW, Pretlow TG,
Harris SE, Wilson EM, Mohler JL \& French FS 1997 Dehydroepiandrosterone activates mutant androgen receptors expressed in the androgen dependent human prostate cancer xenograft CWR22 and LNCaP cells. Molecular Endocrinology $11450-459$.

Thalmann GN, Anezinis PE, Chang SM, Zhau HE, Kim EE, Hopwood VL, Pathak S, von Eschenbach AC \& Chung LW 1994 Androgen independent cancer progression and bone metastasis in the $\mathrm{LNCaP}$ model of human prostate cancer. Cancer Research 54 2577-2581.

Tilley WD, Wilson CM, Marcelli M \& McPhaul MJ 1990 Androgen receptor gene expression in human prostate carcinoma cell lines. Cancer Research 50 5382-5386.

Tung L, Mohamed MK, Hoeffler JP, Takimoto GS \& Horwitz KB 1993 Antagonist occupied human progesterone B receptors activate transcription without binding to progesterone response elements and are dominantly inhibited by A receptors. Molecular Endocrinology 7 $1256-1265$.

Van Wyk JJ, Graves DC, Casella SJ \& Jacobs S 1985 Evidence from monoclonal antibody studies that insulin stimulates deoxyribonucleic acid synthesis through the type 1 somatomedin receptor. Fournal of Clinical Endocrinology and Metabolism 61 639-677.

Vegeto E, Shahbaz MM, Wen DX, Goldman ME, O'Malley BW \& McDonnell DP 1993 Human progesterone A form is a cell and promoter specific repressor of human progesterone B function. Molecular Endocrinology 7 1244-1255.

Wainstein MA, He F, Robinson D, Kung HJ, Schwartz S, Giaconia JM, Edgehouse NL, Pretlow TP, Bodner DR, Kursh ED, Resnick MI, Seftel A \& Pretlow TG 1994 CWR22: androgen dependent xenograft model derived from a primary human prostatic carcinoma. Cancer Research $\mathbf{5 4}$ 6049-6052.

Wilson EM \& French FS 1979 Effects of proteases and protease inhibitors on the $4.5 \mathrm{~S}$ and $8 \mathrm{~S}$ androgen receptor. Fournal of Biological Chemistry 254 6310-6319.

Wilson CM \& McPhaul MJ 1994 A and B forms of the androgen receptor are present in human genital skin fibroblasts. PNAS 91 1234-1238.

Wilson CM \& McPhaul MJ 1996 A and B forms of the androgen receptor are expressed in a variety of human tissues. Molecular and Cellular Endocrinology 120 51-57.

Wu HC, Hsieh JT, Gleave ME, Brown NM, Pathak S \& Chung LW 1994 Derivation of androgen independent human LNCaP prostatic cell sublines: role of bone stromal cells. International Fournal of Cancer 57 406-412.

Yarbrough WG, Quarmby VE, Simental JA, Joseph DR, Sar M, Lubahn DB, Olsen KL, French FS \& Wilson EM 1990 A single base mutation in the androgen receptor gene causes androgen insensitivity in the testicular feminized rat. Fournal of Biological Chemistry 265 8893-8900.

Yudt MR \& Cidlowski JA 2001 Molecular identification and characterization of A and B forms of the glucocorticoid receptor. Molecular Endocrinology 15 1093-1103.

Zegers ND, Claassen E, Neelen C, Mulder E, van Laar JH, Voorhorst MM, Berrevoets CA, Brinkmann AO, van der Kwast TH, Ruizeveld de Winter JAR, Trapman J \& Boersma WJA 1991 Epitope prediction and confirmation for the human androgen receptor: generation of monoclonal antibodies for multi-assay performance following the synthetic peptide strategy. Biochimica et Biophysica Acta $107323-32$.

RECEIVED IN FINAL FORM 19 July 2001 ACCEPTED 27 July 2001 